\title{
Management and Curriculum Development
}

\author{
Kasypul Anwar \\ Counseling Guidance Study Program \\ Universitas Islam Kalimantan \\ Banjarmasin, Indonesia \\ kasypul.a@yahoo.com
}

\begin{abstract}
Learning objectives are one aspect that needs to be considered in learning planning. In an effort to improve the quality of education, one important component in it is the curriculum. Therefore, the curriculum must be well developed and professionally developed. This study aims to find out how management and curriculum development have been carried out. This research used a descriptive qualitative approach. Techniques for collecting data was done through documentation (collecting information from various sources). Based on the results and discussion, it is known that the curriculum management contains a cooperative management system that is cooperative, comprehensive, systemic, and systematic in order to realize the achievement of curriculum objectives. The management of curriculum development is a curriculum management process or system that is cooperative, comprehensive, systemic, and holistic that refers to the achievement of educational goals (curriculum) that has been formulated. The management process of curriculum development cannot be separated from Team Work (collaboration) with the help of resources that support it.
\end{abstract}

Keywords-Management, Development, Curriculum

\section{INTRODUCTION}

One aspect that needs to be considered in planning the learning is learning objective. This is because all learning activities start at achieving the goal. Various efforts have been made by the government to realize these educational goals, including curriculum changes. Learning in essence is a continuous process of activities in order to constructively change students' behavior which includes cognitive, affective, and psychomotor aspects. The learning process is a process that is complex, comprehensive, and continuous. Educators act as managers of teaching and learning and as facilitators who try to create conditions for effective teaching and learning, develop learning materials well, and improve the ability of students to listen to lessons and master educational goals that must be achieved. Fulfillment of these objectives can be achieved if educators are able to manage learning that provides stimulation to students so that an enthusiastic attitude arises in learning because students are the main subject in learning.

Along with the needs and demands of the people who are full of developments in science and technology, the curriculum should be given efforts to change, develop and innovate towards these demands. A necessity if the curriculum continues to present with patterns of change as a result of people's thinking because the "user" of the curriculum is ultimately also the community.
The low quality of education can produce low human resources, this is illustrated in a study of the Human Development Index, that Indonesia is under Vietnam. Various efforts have been made to improve the quality of education, including curriculum changes, starting and 1975 curriculum, 1984 Competency Based Curriculum (KBK), Curriculum Education Unit Level (KTSP) and the latest is the 2013 Curriculum known as Kurtilas.

There are three factors that cause the quality of education not to increase evenly: First; policies and implementation of national education are not implemented consistently. Second; the implementation of national education is carried out in a centralized bureaucratic manner. Third; lack of community participation in the world of education. So, with the changes in the community demanding adjustments in various aspects in accordance with the statements contained in the Republic of Indonesia Law Number 20 of 2003 concerning the National Education System. The implementation of this policy will bring a number of changes in various aspects and dimensions of education. Therefore, wisdom is needed that truly remembers the application of this policy regarding the future of the nation.

The 2013 curriculum is the latest program launched when the National Education Department starts in 2013 as a form of development from the previous curriculum, namely the 2006 curriculum or Education Unit Level Curriculum which includes integrated attitude, knowledge and skills competencies. This is in line with the explanation outlined in article 1 paragraph 29 of UU no.2 year 2003 that the curriculum is a regulation regarding the purpose, content, and material of learning and the method used as a guideline for the implementation of learning activities to achieve certain educational goals.

In a broader concept, the curriculum is interpreted as a set of structured learning experiences that students must follow in achieving educational goals. Curriculum 2013 is the latest curriculum which is a development of a pre-existing curriculum, both the Competency Based Curriculum which was initiated in 2004 and the Education Unit Level Curriculum in 2006. It's just that the press point in the 2013 Curriculum is an improvement and soft balance skills and hard skills which include aspects of spiritual competence and social attitudes, skills, and knowledge.

Facing various challenges in curriculum change requires the quality of teachers who are able to realize professional performance in the nuances of education with adequate welfare support and in the relationship of legal certainty. The teacher is a term for position and profession for someone who devotes 
himself in the field of education through educated, patterned, formal and systematic interaction. Besides that, the curriculum must be well-developed and professionally developed. This study aims to find out how management and curriculum development have been carried out.

\section{LITERATURE REVIEW}

\section{A. Management}

Reference [1] state that "management is getting things done through the efforts of other people". Meanwhile, Siagan in the book "Administrative Philosophy" define management as the ability or skill to obtain an outcome in order to achieve goals through other people. Ordway Tead adapted by Rosyidi in the book Organization and Management defines it as the process and implementation of business activities and directs the direction of implementation the task of an organization in realizing its intended purpose. Therefore, management is a typical process that consists of planning, organizing, mobilizing and controlling actions taken to determine and achieve the determined goals through the use of human resources and other sources.

Specifically, in the field of education, education is inseparable from the importance of management of education. So, the definition of management of education is needed as a system of systematic. It is a systemic and comprehensive cooperation in the context of realizing national education goals. Management of education can also be interpreted as everything related to the management of the educational process to achieve set goals, both short-term, medium-term, and longterm goals [2].

In line with the notion of education management, it cannot be separated from the notion of curriculum management which implies a cooperative, comprehensive, systemic, and systematic curriculum management system in order to realize the achievement of curriculum objectives. Curriculum management is an integral part of the 2013 curriculum and School Based Management (SBM). Meanwhile, the scope of curriculum management includes planning, organizing, implementing, and evaluating [3].

\section{B. Curriculum Development}

Reference [4] defines a curriculum as plans that are made to guide learning in school usually include documents, levels in general, and the actualization of plans in class, as student experiences that have been recorded and written by an expert experiences. It is placed in a learning environment that also influences what is learned.

Whereas, according to Law Number 20 of 2003 concerning the National Education System, the curriculum is a set of plans and arrangements regarding the purpose, content, and material of learning and the methods used as guidelines for the implementation of learning activities to achieve certain educational goals. These specific objectives include the objectives of national education as well as conformity with specificities, conditions, and potential of the region, educational units and students. Therefore, the curriculum is compiled by educational units to enable the adjustment of educational programs to the needs and potential in their respective regions. The development of a diverse curriculum refers to national education standards to ensure the achievement of national education goals. The curriculum is the most important tool in the success of education. Without the existence of a good and appropriate curriculum, it will be difficult to achieve the goals and objectives of education both formal, informal, and informal.

From various kinds of understanding of the curriculum in language terms and curriculum meaning based on experts, curriculum management can be interpreted as a process or system of curriculum management in a cooperative, comprehensive, and systematic way to refer to the achievement of curriculum objectives that have been formulated. In the process of management, the curriculum cannot be separated from the social collaboration between two or more people formally with the help of resources that support it. Implementation is carried out with certain effective and efficient work methods regarding energy and costs and refers to curriculum objectives that have been predetermined [5].

\section{METHOD}

This study used a qualitative descriptive approach. The method employed was a literature study by gathering as much information as possible from various sources.

\section{RESUlTS AND DisCUSSION}

The concept of curriculum development can be interpreted from two types of processes, namely development in the sense of engineering and development in the sense of construction. The curriculum development is an activity to produce a new curriculum through the steps to formulate the curriculum on the basis of the results of the assessment carried out during a certain period [6].

The process of curriculum development in the first sense consists of four stages, namely; first, determine the Foundation (the basics needed to develop the curriculum). Second, determine the construction (returning the expected curriculum model based on the foundation). Third, implementation (implementation of the curriculum). Fourth, evaluation (assessing the curriculum comprehensively and systemically).

The process of curriculum development in the second sense, namely: micro development process, which is outlined through four process activities, namely; design goals, formulate material, establish methods, and design evaluations. Curriculum development based on management means implementing curriculum development activities based on management's mindset, or based on management processes in accordance with management functions, in this case, seen the management function Gregg argues that management functions include; decision making, planning, organizing, communicating, influiting, coordinating, and evaluating. Meanwhile, according to Litchfield, the management function consists of; decision making, programming, communicating, controlling, and reappraising. Then, according to Campbell, the management functions include: decision making, programming, stimulating, coordinating, and appraising. 
Robinson tried to compromise various views above and stated that the most basic and must exist ones in management functions are; Planning, Organizing, Actuating, and Controlling known as POAC. The first is planning a curriculum designed based on needs analysis, using a particular model that refers to effective curriculum design. The second is organizing the curriculum that is structured both structurally and functionally. The third is the implementation of the curriculum is the implementation of the curriculum in the field. The fourth is monitoring the curriculum which includes curriculum evaluation.

In the first curriculum development management, it consists of four stages. First, determine the foundation, namely the basics needed to develop the curriculum. Second, construct it by returning the expected curriculum model based on the foundation). Third, implement it by implementing the curriculum. The last, evaluate it by assessing the curriculum comprehensively and systemically. This is a macro curriculum approach. As it is known that the curriculum is a system that has components that are interrelated and support each other. The components of the curriculum consist of objectives, learning materials, methods, and evaluations. In the form of this system, the curriculum will run towards an educational goal with mutual cooperation between all sub-systems.

Given the importance of education in an effort to raise dignity and prepare human beings who have intellect, spirituality, and morality, this kind of education requires a hard and serious effort and thought to realize its ideals [7]. If one of the curriculum variables does not function properly, the curriculum system will run less optimally. Management of this curriculum does not only function for students but also functions for educators (teachers). The function of the curriculum for students is the curriculum as an organizational learning experience that is prepared and prepared for students as one of the consumers. With this, it is expected that they will get a number of new experiences that can later be developed in tune with their development in order to complete their life provisions. As a tool in achieving educational goals, the curriculum is expected to be able to offer programs to students who will live in their time, with a sociohistorical and cultural background that is different from the age in which their parents are.

Meanwhile, the curriculum function for teachers is as a guideline for working in compiling and organizing learning experiences for students and becoming a guideline for evaluating students' development in order to absorb the amount of experience given so that in the future they can become people who succeed in the field they are engaged.

With the existence of the curriculum, the task of educators is certainly more directed. Educators are also one of the main keys in determining and very important in the education process, and it is one component that interacts actively with students in education. As a guideline, the curriculum is used as a means to achieve educational goals. The curriculum of a school contains a description of what types of programs are carried out by the school.

The curriculum of an education is not only always static but can change and be dynamic. This is because the curriculum is strongly influenced by environmental changes that require it to make adjustments to meet demand. Demand is good because of the needs of students and the needs of the community who always experience continuous development and growth.

Curriculum improvement is essential to improve the quality of education which can be highlighted in two aspects, namely processes and products. The process criteria focus on the efficiency of the implementation of the curriculum and instructional system, and aim to know and predict the plan and implementation. Meanwhile, the quality of the product looks at the educational goals to be achieved and output (graduation of students). With regard to repair procedures, all components of human resources such as administrators, school owners, principals, teachers, students, and the community also have a big role. The responsibilities of each must be clearly formulated. In addition, the evaluation aspect must also be reviewed from the outset of the curriculum improvement program planning. With proper evaluation and accurate information, data will be very necessary for making curriculum and instructional decisions.

Curriculum development is a complex process and involves all components that are interrelated and support one component with another component. The curriculum is dynamic and the development must always be held as well as to be able to keep up with the developments and challenges of the times. Curriculum development must be carried out systematically and directed, must have a clear vision and mission, and be brought to where national education is going forward with the development of the curriculum.

2013 Curriculum Development must be able to equip students with various competencies. Reference [8] explains that the competencies needed in the future are namely the ability to communicate, think clearly and critically, consider the moral aspects of a problem, be a responsible citizen, try to understand and tolerate different views, live in a globalized society, have a broad interest in life, have readiness to work, have intelligence in accordance with their talents/interests, and have a sense of responsibility towards the environment. The 2013 curriculum that has been compiled by the school is applied by the teacher in the learning process. In the learning process itself. there are many interrelated components, including the curriculum to be delivered in the form of goals as well as teaching materials or materials, methods, and evaluation. The teacher makes the component in the form of a syllabus and learning implementation plan submission of the learning process is also strongly influenced by the teacher as the executor of the activity. In addition, the students also influence the learning process.

\section{CONCLUSION}

Based on the results and discussion of this study, it can be concluded that curriculum management contains a cooperative, comprehensive, systemic, and systematic curriculum management system in order to realize the achievement of curriculum objectives. Curriculum development management is a process or system of curriculum management that is cooperative, comprehensive, systemic, and systematic (holistic) that refers to the achievement of educational objectives 
(curriculum) that have been formulated. The management process of curriculum development cannot be separated from the team work (collaboration) with the help of resources that support it. The implementation with certain strategies that are effective and efficient, as well as referring to the vision, mission, and goals that have been predetermined. Curriculum development is a complex process and involves all components that are interrelated and support one component with another component. In 2013 Curriculum Development, teachers must be able to equip students with various competencies. Competencies needed in the future are; ability to communicate, think clearly and critically, consider the moral aspects of a problem, be a responsible citizen, try to understand and tolerate different views, live in a globalized society, have a broad interest in life, readiness to work, intelligence in accordance with their talents/interests, and a sense of responsibility towards the environment.

\section{REFERENCE}

[1] K. Koontz, and O. Donnel, Principles of management and analysis of management function, 5th ed, Mc Graw Hill, 2006.

[2] G. Gaffar, Perencanaan pendidikan teori dan metodologi, Jakarta: P2LPTK, 1989.

[3] R. Rusman, Manejeman kurikulum, Jakarta: Rajawali Pers. 2009.

[4] A. Nurhayati, Inovasi kurikulum; telaah terhadap pengembangan kurikulum pendidikan pesantren, Yogyakarta: Teras, 2010,

[5] S. Sulistyorini, Manajemen pendidikan islam, Yogyakarta: Teras, 2009,

[6] H. Baharun, Pengembangan kurikulum; teori dan praktik (konsep, prinsip, pendekatan dan langkah-langkah pengembangan kurikulum PAI, Yogyakarta: CV Cantrik Pustaka, 2017.

[7] E. Mulyasa, Pengembangan dan implementasi kurikulum 2013. Bandung: Rosdakarya, 2013. 